University of Wollongong

Research Online

Faculty of Business - Papers (Archive)

Faculty of Business and Law

$1-1-2020$

\title{
Towards an environmentally sustainable rental housing sector
}

Troy W. Heffernan

University of Wollongong, troyh@uow.edu.au

Emma Elizabeth Heffernan

University of Wollongong, eheffern@uow.edu.au

Nina Reynolds

University of Wollongong, ninar@uow.edu.au

Wai Jin (Thomas) Lee

University of Wollongong, thlee@uow.edu.au

Paul Cooper

University of Wollongong, pcooper@uow.edu.au

Follow this and additional works at: https://ro.uow.edu.au/buspapers

Part of the Business Commons

Research Online is the open access institutional repository for the University of Wollongong. For further information contact the UOW Library: research-pubs@uow.edu.au 


\title{
Towards an environmentally sustainable rental housing sector
}

\begin{abstract}
Rental houses in Australia represent approximately one third of all homes, and this proportion has been growing over recent decades. However, the quality, comfort and environmental credentials of these houses are often poor, particularly when compared to owner-occupied homes. With climate change, the urgency increases to move to a more sustainable built environment. Consequently, exploring how to make rental properties more sustainable warrants further investigation and action. Using data gathered from a broad range of experts through a four-stage Policy Delphi technique, findings reveal four key enabling forces: communication, facilitation, incentivization, and regulation. These forces both influence and are influenced by rental market conditions. A conceptual framework is presented which highlights the interplay between the stakeholders and enabling forces, which has the potential to lead to a Win-Win-Win scenario for landlords, tenants and the environment. With a clear social and environmental imperative to move to a more sustainable rental sector, this research presents a pathway to reach this goal.

\section{Disciplines}

Business

Publication Details

Heffernan, T. W., Heffernan, E. E., Reynolds, N., Lee, W. \& Cooper, P. (2020). Towards an environmentally sustainable rental housing sector. Housing Studies, Online First 1-24.
\end{abstract}


To cite this article:

Troy W. Heffernan, Emma E. Heffernan, Nina Reynolds, Wai Jin (Thomas) Lee \& Paul Cooper (2020) 'Towards an environmentally sustainable rental housing sector', Housing Studies, DOI: $\underline{10.1080 / 02673037.2019 .1709626}$

\title{
TOWARDS AN ENVIRONMENTALLY SUSTAINABLE RENTAL HOUSING SECTOR
}

\begin{abstract}
Rental houses in Australia represent approximately one third of all homes, and this proportion has been growing over recent decades. However, the quality, comfort and environmental credentials of these houses are often poor, particularly when compared to owner-occupied homes. With climate change, the urgency increases to move to a more sustainable built environment. Consequently, exploring how to make rental properties more sustainable warrants further investigation and action. Using data gathered from a broad range of experts through a four-stage Policy Delphi technique, findings reveal four key enabling forces: communication, facilitation, incentivisation, and regulation. These forces both influence and are influenced by rental market conditions. A conceptual framework is presented which highlights the interplay between the stakeholders and enabling forces, which has the potential to lead to a Win-Win-Win scenario for landlords, tenants and the environment. With a clear social and environmental imperative to move to a more sustainable rental sector, this research presents a pathway to reach this goal.
\end{abstract}

\section{KEYWORDS}

Private rental sector; sustainable housing; climate change; retrofitting; Policy Delphi; Australia 


\section{Introduction}

A growing urgency to act on climate change has been spurred by scientific reports outlining the seriousness of the crisis (e.g. the Intergovernmental Panel on Climate Change, 2018). Temperature records around the globe are being broken year-on-year, and the frequency and intensity of extreme weather events is increasing (Pachauri \& Meyer, 2015). World leaders are identifying climate change as a key challenge facing society (World Economic Forum, 2019; Wrigley \& Crawford, 2015). Consequently, political intervention designed to reduce climate change is gaining momentum (at least in most parts of the world). This momentum was exhibited with the 2015 Paris Climate Agreement, heralded by the United Nations secretary general, Ban Ki-moon, as 'truly a historic moment' for 'one of the most crucial problems on earth' (Davenport, 2015). However, tangible action to reduce emissions in Australia has been limited at best, with carbon dioxide $\left(\mathrm{CO}_{2}\right)$ emissions growing between March 2016 and March 2019 (Australian Government, Department of the Environment and Energy, 2019).

Australia has the dubious distinction of being one of the highest contributors to global greenhouse gas (GHG) emissions both at a country level and on a per capita basis (Lewandowsky, 2011; Prather et al., 2001). In 2014, per capita GHG emissions in Australia were the highest amongst the 36 member countries of the Organisation for Economic Cooperation and Development (OECD) (Organisation for Economic Co-operation and Development, 2018). Under the Paris Agreement of 2015, Australia has committed, by the year 2030, to reducing GHG emissions to 26-28 percent below 2005 levels (Australian Government Department of the Environment and Energy, 2017). Consequently, the Australian Government needs to consider a range of ways by which the nation can achieve these reduction targets.

Globally, the building sector has been identified as the sector with the most potential for low-cost climate change mitigation strategies (Ghaffarianhoseini et al., 2013). In 2016, the residential housing sector was estimated to be responsible for 11.4 percent of Australia's GHG 
emissions (Australian Government Department of the Environment and Energy, 2018). Efforts so far in the housing sector have often focused on reducing the carbon footprint of new housing, and policy solutions in Australia have supported this for some years (e.g. National Home Energy Rating Scheme (Department of the Environment and Energy, 2019); National Construction Code (Australian Building Codes Board, 2016); and Building Sustainability Index (BASIX)(NSW Government, 2019)). However, new housing only accounts for a small percentage of the total housing stock (around 2 percent of the building stock in Australia is replaced in any one year (Australian Building Codes Board , 2016)), and the majority of the private rental sector (PRS) housing stock pre-dates the 2003 introduction of energy efficiency legislation (Gabriel et al., 2010).

Similar to many international markets (Byrne, 2019), there has been strong growth in the Australian PRS over the past decade. From 2006 to 2016, the rental sector in Australia increased by 38 percent, double the rate of overall household growth (Hulse et al., 2018), and rental dwellings now account for 30.9 percent of homes in Australia (Australian Bureau of Statistics, 2016). Despite this increase in quantity, rental houses have previously been criticised for being of poor quality and including limited features to combat climate change (Instone et al., 2015). Consequently, PRS housing stock generally demands more energy than owneroccupied housing to maintain minimal comfort. Yet landlords are less likely to implement energy efficiency measures than homeowners (Wrigley \& Crawford, 2015), and tenants often have limited capacity to make energy efficiency or comfort improvements to a house they do not own. As such, measures that result in improving the Australian PRS housing stock represent a significant opportunity to reduce the country's carbon footprint. However, there has been limited research into stakeholder attitudes and motivations regarding the imperative of improved environmental sustainability in rental houses, and how this might translate into adoption of sustainable practices in the Australian PRS (Instone et al., 2015). 
To address the above issue, we unpack the enablers and barriers of an environmentally sustainable PRS, and extend prior research (e.g., Instone et al., 2015; Wrigley \& Crawford, 2015 ) to adopt a comprehensive approach for achieving this task. Specifically, we explore the complexity of this process, with its competing agendas, multiple stakeholders and varied solutions to present a framework that navigates these profound challenges and presents a way forward. Consequently, this study examines two important research questions:

1. What are the barriers and enablers for undertaking environmentally sustainable retrofitting of rental premises?

2. What is an appropriate conceptual framework for moving towards an environmentally sustainable private rental sector?

The remainder of this paper is structured as follows. After a review of the literature in the relevant bodies of research, policy and practice, the adopted methodology is justified. Next, the collected data is presented and analysed. This is followed by a discussion of the findings and the introduction of a framework that highlights the key forces which need to be considered when developing policy and market-based solutions to enhance the environmental sustainability of existing rental properties. In the final section, implications and suggestions for further research are presented and conclusions drawn.

\section{The Private Rental Sector in Australia}

The PRS has recently seen the strongest growth of all forms of housing tenure in Australia. In 2016, 2.1 million homes, or 26 percent of all households, were in the PRS (Hulse et al., 2018), with the remainder of rental properties being within the public sector. The growth of the PRS is mirrored in the USA, the UK, New Zealand and Ireland (Chisholm et al., 2017; Crook \& Kemp, 2014; Duffy et al., 2017; Hulse \& Yates, 2017; Whitehead et al., 2016). This is in stark contrast to the decline within the social housing rental sector in Australia, which contracted by approximately 5 percent between 2011 and 2016 (Hulse et al., 2018), limiting the ability of 
policymakers in Australia to implement rental affortablity schemes that have been possible elsewhere (e.g. 'Living Rent' scheme in London (Padley \& Marshall, 2019)). In NSW alone, there are 750,000 PRS households (State of NSW and Office of Environment and Heritage, 2016), while in the state of Victoria, 33 percent of all households are in the PRS (Martinelli, 2017). Previous studies have shown that the energy efficiency of housing in the PRS is lower than that of owner occupied housing (Pitt \& Sherry, 2014). Further, tenants in lower socioeconomic groups are twice as likely to occupy a home without insulation when compared to owner-occupied homes (Liu \& Judd, 2019). This situation has also been illustrated in an international context where US tenants consume approximately $2.7 \%$ more energy than owneroccupiers (Melvin, 2018). Consequently, PRS properties are typically poorly positioned to cope with the stresses that climate change will bring (Instone et al., 2015).

Historically, renters in Australia have been low income earners such as single parents, young people, migrants and pensioners (Australian Council of Social Service et al., 2017; Hulse et al., 2012). However, over recent years, demographics have shifted, as families, unable to buy their own home due to rising property prices, have entered the rental market on a longterm basis (Martinelli, 2017; Pawson et al., 2018; Wulff \& Maher, 1998). Despite this change in the profile of renters in Australia, an overrepresentation of low income households living in rental accommodation remains (Australian Council of Social Service, 2013). In Australia, there are approximately 3 million people (including over 730,000 children) surviving below the poverty line (Australian Council of Social Service et al., 2017). The non-house net wealth of renters is approximately one third that of homeowners in Australia (Gabriel et al., 2010). Therefore, as the PRS comprises both predominantly low income households and less energy efficient properties than non-rental homes (Martinelli, 2017), renters will be disproportionately impacted by climate change. In contrast to Australia, many Central European countries, such as Germany, have a long-standing regulatory framework around the PRS (Organisation for 
Economic Co-operation and Development, 2016), which is supported by long-term tenancies and regulation of rents (Scanlon \& Kochan, 2011), allowing tenants a higher level of security in their homes.

In 2013-14, approximately 1.135 million Australian households owned properties in the PRS, with 72 percent of them owning only one rental property (Hulse et al., 2018). The profile of the average PRS landlord is referred to with terms like 'petty landlordism' (Gabriel et al., 2010) and 'mum and dad investors' (Hulse et al., 2018). These terms encapsulate the small-scale nature of investments in the PRS. Therefore, instead of working with professional institutions to address environmental sustainability of the PRS, any policy or market-based solutions need to engage the myriad of small scale investors. It is within this context of multiple stakeholders and competing agendas that barriers and enablers are explored in this paper, leading to the presentation of an integrated framework for the transition to an environmentally sustainable rental sector.

\section{The Social Implications of Housing Quality in the Private Rental Sector}

Besides the environmental imperative for making rental houses more environmentally sustainable, there is also a social imperative. Tenants are likely to be lower income earners (Verstraete \& Moris, 2018), and are potentially more vulnerable to climate change (Instone et al., 2015). The reasons for this are both the relative energy inefficiency of rental houses compared with owner-occupied houses (Martinelli, 2017), and the limited capacity of tenants to improve the energy efficiency of rental premises due to either brevity of leases, costs of upgrades, or landlord restrictions on alterations (Crawford \& Stephan, 2015). This situation is exacerbated by significant increases in residential energy prices over the past decade. In Australia, the price of electricity has increased on average at $8 \%$ per year over the past 10 years (ACCG, 2017); and in real terms, electricity prices rose 52 percent in New South Wales (NSW) over a ten year period to 2018 (New South Wales Parliament Legislative Council, 
2018). Increasing numbers of Australians are struggling to cover the cost of their energy utilities (NSW Council of Social Services, 2017). Indeed, in the State of Victoria, electricity supply disconnections more than tripled in the five-year period from 2008 (from 9,598 to 34,448) (Consumer Action Law Centre, 2015). This is not just an Australian phenomenon, the inability to afford energy, termed 'fuel poverty', is affecting renters worldwide (Bouzarovski \& Petrova, 2015; Pivo, 2014). These dramatic energy price increases have had a multiplying economic effect for low income earners living in less energy efficient houses which require more energy to stay comfortable (Wrigley \& Crawford, 2015). Previous research highlights the negative impact of energy inefficient houses on the health and wellbeing of occupants (Bosch et al., 2019; Cooper et al., 2016; Waitt et al., 2016), as well as the positive health benefits for low income households when energy efficiency upgrades are made (Howden-Chapman et al., 2008). These social and environmental challenges highlight the imperative to examine the most effective ways to increase the environmental sustainability and comfort of rental premises.

\section{Environmental Sustainability in the Private Rental Sector}

Concern has been expressed about the lack of uptake of environmentally sustainable retrofits in the PRS, because this "not only undermines Australia's attempts to reduce GHG emissions, it jeopardises equitable access to energy for low income households" (Wrigley \& Crawford, 2015, p. 322). Limited policy and market attention has been focused on reducing the carbon footprint of the existing PRS housing stock. Governments at local, state and national levels have implemented a number of policies and trials to help enhance the environmental sustainability of rental houses in Australia, but these have typically been neither consistent nor enduring (Gabriel et al., 2010).

Previous research in Australia and internationally has identified barriers and enablers that impede or enhance progress towards making rental properties more environmentally 
sustainable. Projects such as the Low Income Energy Efficiency Program (Button et al., 2016) identify key barriers including costs, information and awareness, culture and split incentives. A recurring theme to emerge relates to the cost of retrofitting rental properties (Hatvani-Kovacs et al., 2015; Hope \& Booth, 2014; Instone et al., 2015; Wrigley \& Crawford, 2015). When considering the profile of the vast majority of landlords in Australia, (ownership of one or two rental properties which makes up a large proportion of their investment portfolio), these upfront costs can have a major impact on not only the profitability of the investment, but also the ability of the landlord to raise the funds to make improvements. To maximise their investment, by reducing their costs, landlords typically make decisions with a focus on price, not energy efficiency; thus, providing houses to the market that require additional energy to maintain comfort levels (Bird \& Hernández, 2012).

Split incentives, in which the costs and benefits of an investment are not perceived to be equally shared between the landlord and the tenants (Bird \& Hernández, 2012; Charlier, 2015), have further increased the complexity of achieving workable solutions. Theoretically, split incentives emerge from the rational choice economics concept of the principle-agent problem (de T'Serclaes \& Jollands, 2007). As tenants usually pay energy bills in the Australian PRS, landlords do not perceive any direct financial benefit from improving the environmental sustainability of their property (Council of Australian Governments Energy Council, 2016). However, emerging research highlights policy interventions that mitigate the impact of split incentives (MacAskill et al., 2019). Further, higher energy efficiency standards (e.g., insulation, double glazing, efficient appliances, and solar panels) have been shown to positively impact the price achieved at rent or sale (Chegut et al., 2016; Fuerst \& Warren-Myers, 2018; Im et al., 2017; Kholodilin et al., 2017). For example, a large scale study in Germany found that energy efficient rental units could demand a premium (Cajias et al., 2019); and at point of sale, energy efficiency labels were shown to have a positive impact on housing prices in the 
UK (Fuerst, 2018). But for this to happen, potential tenants need to be made aware of the environmental sustainability of a property through some form of disclosure regarding the property's energy performance. In the Australian Capital Territory (ACT), providing an Energy Efficiency Rating (EER) statement is mandatory at the point of sale; however, it is only a requirement to provide one at the point of lease if one already exists (Residential Tenancies Act 1997-ACT Legislation Register, 2018). As a result, recent data evidenced that only 26 percent of rental properties analysed in a two-month period were advertised with an EER (Better Renting, 2018). Of those rental homes with an EER, 43 percent received the lowest star rating of zero (compared with only 4 percent of the properties for sale) (Better Renting, 2018).

Another issue to emerge in the literature relates to communication and education for key stakeholders regarding environmentally sustainable retrofits in the PRS. This includes information or knowledge of specific schemes and the overall benefits of retrofitting. For example, Hope and Booth (2014) highlight a lack of awareness amongst landlords about available schemes for retrofitting in the UK. Likewise in Australia, landlords have found it difficult to access similar information (Australian Council of Soial Sciences, 2013; Council of Australian Governments Energy Council, 2016; Gabriel et al., 2010; Instone et al., 2015; Wrigley \& Crawford, 2015). This state of imperfect information access can lead to stakeholders making poor decisions regarding retrofitting in the PRS- a form of market failure (Productivity Commission, 2012).

A contextual theme that emerged from the literature, which could either help or hinder the move to a more sustainable rental sector, was market conditions. With a shortage of rental housing that is coupled with the insecurity of short term leases, there is little incentive for either the tenant or the landlord to improve the property in terms of energy efficiency (Instone et al., 2015; Wrigley \& Crawford, 2015). Even when renters were motivated to reduce their carbon footprint and propose environmental retrofits with associated incentives, landlords were 
typically unwilling to give permission (Martinelli, 2017). However, research into the insecurity within the rental market and the interplay between stakeholders and key enabling forces is surprisingly lacking.

The case for retrofitting is supported not only by environmental imperatives, but also social and economic drivers. Consequently, it is important to identify the interplay between key enablers and barriers for environmentally sustainable retrofitting of the Australian PRS. A more holistic understanding of this complex issue is needed to have a chance of successfully moving to an environmentally sustainable rental sector.

\section{Methodology}

A research methodology was needed that did not limit, but rather embraced the potentially divergent views of key stakeholders. The Policy Delphi technique is one such method and was adopted for this study. The Policy Delphi technique (Linstone \& Turoff, 1975; Turoff, 1970), a variation of the Delphi technique, generates differing views within a group of experts, with the aim of uncovering new and creative policy solutions (Needham \& De Loe, 1990).

Heterogeneity of the sample group is a key characteristic of the Policy Delphi technique (Paraskevas \& Saunders, 2012), which adds to the richness of debate within the research (Rubin \& Rubin, 2005). Consequently, maximum variation sampling (Tracy, 2013) under a purposive sampling strategy (Teddlie \& Yu, 2007) was adopted for this study. Purposive techniques relate to a sampling design based on a clear purpose in selecting respondents (Teddlie \& Tashakkori, 2003). For this study, the objective of using maximum variation sampling was to examine this complex topic from all points of view (Etikan et al., 2016) in order to gain a greater appreciation of how to achieve positive movement towards a more environmentally sustainable rental sector.

From an examination of the literature, nine stakeholder groups were identified as needing a voice within this study (see Table 1, noting that respondents were able to self-identify 
in multiple categories). Experts or 'informed advocates' (Paraskevas \& Saunders, 2012) from the nine groups were identified by internet searches and recommendations from key researchers in the field. Potential panel members within the stakeholder groups were approached based on their experience, standing and/or research. The participants were not expected to have an expert understanding of all facets of the problem. It should be noted that the small number of tenants $(n=2)$ identified in Table 1, does not highlight the full voice tenants had in this process, as two of the three advocacy group participants were representatives of tenants' rights advocacy organisations.

Table 1. Self-identified roles of Policy Delphi participants.

\begin{tabular}{ll}
\hline Expert Role(s) (multiple roles possible) & Number* \\
\hline Landlord & 12 \\
Tenants & 2 \\
Property Managers & 9 \\
Consultant/Researchers (Housing) & 7 \\
Consultant/Researchers (Environment) & 7 \\
Advocacy Groups/Industry Associations & 3 \\
Government (Policy) & 6 \\
Builder/Tradespeople & 2 \\
Finance Industry (Housing) & 4 \\
\hline
\end{tabular}

* Note: Respondents were able to self-identify in multiple categories

From the 56 experts that were invited to participate, 34 agreed and responded to Round 1 - a 61 percent response rate. This is within sample size boundaries suggested by Turoff (1970) (10 to 50 participants) and slightly more than that suggested by Rayens and Hahn (2000) (10 to 30 participants). As shown in Table 2, 34 experts responded for Round 2. However, five of these experts had, for various reasons, not been able to participate in Round 1, and wanted to be part of the study. After an examination of the responses provided by these five participants in Rounds 2 and 3, it was deemed appropriate to retain their data in the study. In Round 3, 26 experts replied, which was a response rate of 76 percent, meaning an attrition of eight experts since the previous round. Following precedent for the use of interviews for follow-on enquiry 
based on Delphi findings (Powell, 2002), this project utilised a fourth-round of data collection. A subset of six experts from the panel were identified and asked to participate in an in-depth interview (all agreed).

Table 2. Respondents per round and response rate.

\begin{tabular}{lccc}
\hline Respondents Per Round: & Invited & Responded & Response Rate \\
\hline Round 1 & 56 & 34 & $61 \%$ \\
Round 2 & $39 *$ & 34 & $87 \%$ \\
Round 3 & 34 & 26 & $76 \%$ \\
Round 4 (In-depth interviews) & 6 & 6 & $100 \%$ \\
\hline
\end{tabular}

*Note: Five experts that did not complete Round 1 were involved in Rounds 2 and 3.

The first three rounds of the Policy Delphi study were undertaken online using the Qualtrics survey software. Before each round was sent to experts, a thorough pre-testing phase was undertaken, both internally within the research team, and externally by experts with an understanding of methods and/or the topic area. Six external experts were used for the pre-test of each round.

Round 1 was predominantly qualitative in nature, with open-ended questions attempting to elicit information relating to major enablers and barriers to environmentally sustainable retrofitting of rental properties and the interplay between them. The data generated in this round were analysed thematically, as is typical for the analysis of first round Policy Delphi data (Bailey et al., 2012). NVivo Pro, qualitative data analysis software, aided in management of the data and the identification of key themes. Round 2 of the Policy Delphi study presented key enabling factors back to the experts to gain further qualitative and quantitative insights. A series of statements were developed, where experts were asked to indicate their level of agreement using a five-point Likert scale (Picavet et al., 2012). These questions were analysed using means and consensus analysis (de Loe, 1995). Under each Likert scale a qualitative question was asked, encouraging the experts to explain why they responded in that way. In addition, there were open-ended questions to capture general comments and 
observations from the panel. The quantitative data from this online survey were analysed using SPSS 23.

In Round 3 of the Policy Delphi study, areas of low consensus from Round 2 were examined. With the exception of a final comments question, this round used quantitative questions in order to identify the strength of agreement across the key themes amongst the different stakeholder groups. In Round 4, six experts from the panel, covering key stakeholder groups participated in in-depth interviews, all agreed to participate. The objectives of this round of data collection were to unpack findings where clarity was needed, and validate key themes that had emerged from the data in the previous three rounds. These in-depth interviews were open in nature and started with a presentation of the key themes followed by general discussion.

\section{Findings}

In this section, findings from the analysis of the data are presented for each of the four rounds of the Policy Delphi study. This process was followed to ensure a clear link was identified for the emergent themes through the research process. Anonymised quotes from the panel are used herein to allow the voice of the experts to emerge.

\section{Policy Delphi Round 1:}

In the first round, 34 experts responded to open-ended questions exploring the enablers and barriers to undertaking environmentally sustainable retrofitting of rental properties. As shown in Tables 3 and 4, six barriers and six enablers emerged that are categorised as follows: incentivisation (return on investment, upfront cost reduction), communication (lack of awareness, education), facilitation (ease of implementation), regulation (increase legislation), and the contextual theme of rental market conditions. 
Table 3. Barriers to Environmentally Sustainable Retrofitting of Rental Houses.

\begin{tabular}{|c|c|c|}
\hline Barriers to ESR & Examples & Quotes from Experts \\
\hline $\begin{array}{l}\text { Initial Financial } \\
\text { Barriers } \\
\text { (Incentivisation) }\end{array}$ & $\begin{array}{l}\text { - Loss of rent during works } \\
\text { - Cost of retrofits } \\
\text { - Focus only on financial } \\
\text { benefits } \\
\text { - Undervaluing of retrofit } \\
\text { benefits }\end{array}$ & $\begin{array}{l}\text { Much of these elements (except insulation) } \\
\text { often require quite large investments, and } \\
\text { without a tangible return this limits their } \\
\text { engagement and enthusiasm for retrofitting. }\end{array}$ \\
\hline $\begin{array}{l}\text { Return on } \\
\text { Investment } \\
\text { (Incentivisation) }\end{array}$ & $\begin{array}{l}\text { - Long payback periods } \\
\text { - No tax rebates for } \\
\text { sustainable retrofits } \\
\text { - Hard to value comfort } \\
\text { - Split incentive }\end{array}$ & $\begin{array}{l}\text { Split incentive - the benefits of upgrades are } \\
\text { not enjoyed by the landlord but the costs are } \\
\text { borne by the landlord. }\end{array}$ \\
\hline $\begin{array}{l}\text { Lack of Awareness } \\
\text { (Communication) }\end{array}$ & $\begin{array}{l}\text { - Lack of communication on } \\
\text { performance of retrofits } \\
\text { - Perceived lack of benefits } \\
\text { for landlord } \\
\text { - Lack of reliable } \\
\text { information } \\
\text { - Agents lack knowledge of } \\
\text { benefits }\end{array}$ & $\begin{array}{l}\text { People do not correctly value such features } \\
\text { (like double glazing) partly because they are } \\
\text { uneducated and secondly because it is very } \\
\text { hard to put a price on comfort. }\end{array}$ \\
\hline $\begin{array}{l}\text { Lack of } \\
\text { Regulations } \\
\text { (Regulations) }\end{array}$ & $\begin{array}{l}\text { - No minimum standards for } \\
\text { energy efficiency } \\
\text { - Lack of political drive }\end{array}$ & $\begin{array}{l}\text { There is no socially accepted standard of } \\
\text { minimum performance (either regulated or } \\
\text { accepted by the majority of householders). So } \\
\text { no expectation of what is good/acceptable. }\end{array}$ \\
\hline $\begin{array}{l}\text { Difficulty of } \\
\text { Implementation } \\
\text { (Facilitation) }\end{array}$ & $\begin{array}{l}\text { - Health and safety risks } \\
\text { (e.g. asbestos) } \\
\text { - 'Hassle factor' } \\
\text { - Strata issues } \\
\text { - Physical/technical barriers }\end{array}$ & $\begin{array}{l}\text { Hassle - access, identification and project } \\
\text { management of the upgrades are a hassle to } \\
\text { organise with the property manager or the } \\
\text { tenant. }\end{array}$ \\
\hline $\begin{array}{l}\text { Rental Market } \\
\text { Conditions }\end{array}$ & $\begin{array}{l}\text { - Over-inflation of rental } \\
\text { market } \\
\text { - Lack of demand from } \\
\text { tenant } \\
\text { - Uncertainty of tenancy } \\
\text { length }\end{array}$ & $\begin{array}{l}\text { Current market dynamics (tight market, low } \\
\text { [vacancy] rates, rental affordability } \\
\text { problems, high housing prices) limit tenant } \\
\text { choice and potential for them to influence in } \\
\text { the 'property offerings', particularly in lower } \\
\text { income rental markets (they are takers in } \\
\text { tight markets). }\end{array}$ \\
\hline
\end{tabular}


Table 4. Enablers for Environmentally Sustainable Retrofitting of Rental Houses.

\begin{tabular}{|c|c|c|}
\hline Enablers for ESR & Examples & Quotes from Experts \\
\hline $\begin{array}{l}\text { Return on } \\
\text { investment } \\
\text { (Incentivisation) }\end{array}$ & $\begin{array}{l}\text { - Feed-in-tariff to landlord } \\
\text { - Facilitate utilities to be } \\
\text { included in rental } \\
\text { - Reduced running costs } \\
\text { - Tax-based incentives } \\
\text { linked to sustainability } \\
\text { upgrades } \\
\text { - Rates discounts }\end{array}$ & $\begin{array}{l}\text { ROI of retrofitting; at least it should make a } \\
\text { balance. That is to say, over a reasonable } \\
\text { period, I can have sounds break even } \\
\text { possibilities by comparing the cost against the } \\
\text { savings, plus any incentive scheme for } \\
\text { environmental friendly upgrade. }\end{array}$ \\
\hline $\begin{array}{l}\text { Upfront cost } \\
\text { reduction } \\
\text { (Incentivisation) }\end{array}$ & - Grants/subsidies & $\begin{array}{l}\text { Economic factors would either encourage or } \\
\text { discourage majority of landlords to upgrade } \\
\text { their rental premises. Incentives, e.g. through } \\
\text { Government rebates and tax incentives etc. } \\
\text { would offer landlords a subsidy on the total } \\
\text { cost. }\end{array}$ \\
\hline $\begin{array}{l}\text { Ease of } \\
\text { implementation } \\
\text { (Facilitation) }\end{array}$ & $\begin{array}{l}\text { - DIY Retrofits } \\
\text { - 'Turnkey' solutions } \\
\text { - Low maintenance }\end{array}$ & $\begin{array}{l}\text { If it was easy-if landlords could outsource the } \\
\text { whole process (diagnosis of needs, quotes, } \\
\text { selection, installation, payment) this may } \\
\text { attract them. }\end{array}$ \\
\hline $\begin{array}{l}\text { Increased } \\
\text { legislation } \\
\text { (Regulation) }\end{array}$ & $\begin{array}{l}\text { - Minimum energy } \\
\text { efficiency standards } \\
\text { - Mandatory disclosure } \\
\text { - Mandatory replacement } \\
\text { of inefficient technology } \\
\text { - Policy stability }\end{array}$ & $\begin{array}{l}\text { Given other recent experience of other } \\
\text { programs where landlords were encouraged } \\
\text { to do things that are in the public interest, or } \\
\text { in the interest of their tenants, it may be that } \\
\text { ultimately landlords will need to be required, } \\
\text { rather than encouraged to undertake } \\
\text { retrofitting. }\end{array}$ \\
\hline $\begin{array}{l}\text { Education } \\
\text { (Communication) }\end{array}$ & $\begin{array}{l}\text { - Evidence the benefits } \\
\text { - Raise awareness of } \\
\text { benefits of retrofitting/ } \\
\text { renewables } \\
\text { - Utilities information for } \\
\text { tenants }\end{array}$ & $\begin{array}{l}\text { Education of tenants to assess performance of } \\
\text { dwellings orientation, climate control } \\
\text { landscaping, efficient appliances, productive } \\
\text { gardens. }\end{array}$ \\
\hline $\begin{array}{l}\text { Rental market } \\
\text { conditions }\end{array}$ & $\begin{array}{l}\text { - Facilitating long-term } \\
\text { tenancies } \\
\text { - Change standard tenancy } \\
\text { agreements } \\
\text { - Landlords needing to } \\
\text { compete for tenants } \\
\text { - Changes to strata rules }\end{array}$ & $\begin{array}{l}\text { Deflation of property bubble - refocus } \\
\text { landlords on the use of the building rather than } \\
\text { asset value increase. Giving importance to } \\
\text { good tenants will be of the essence. Landlords } \\
\text { would keep properties well maintained to get } \\
\text { maximum rent as capital gain would not be } \\
\text { there. }\end{array}$ \\
\hline
\end{tabular}

Under incentivistation there were two key barriers that needed to be overcome and two enablers that needed to be embraced. Firstly, initial financial barriers: 'these elements often 
require quite large investments'. Considering the previously discussed demographic breakdown of private landlords in Australia - the majority being small scale investors owning only one rental property (Hulse et al., 2018) - a reluctance or inability to fund retrofits is perhaps unsurprising. Secondly, a further perceived economic barrier was return on investment (ROI), as evidenced by these quotes: 'The majority of landlords are only interested in financial return on their investment'.... 'Most landlords seek to maximise rental returns and minimise expenses, ' leading to a perception of split incentives: 'Split incentive. There are no drivers for landlords to retrofit properties - no financial gain from doing so!' and 'Split incentive - the benefits of upgrades are not enjoyed by the landlord but the costs are borne by the landlord'. The introduction of economic incentives, either targeting return on investment or upfront cost reduction, was seen by the expert panel as a way to encourage landlords to improve the environmental sustainability of their properties:

'Profitability of the investment i.e., will they get a greater financial return as a result of the retrofit either through increased occupancy rates/tenant retention rates (and commensurate tenant demand for these features), reduced maintenance costs, minimum risk to landlord in terms of operating issues.'

Communication emerged both as a barrier, due to lack of awareness or knowledge, and as an enabling force, as a means of education (Tables 3 and 4). This theme relates not only to the knowledge of the landlord, but also to the knowledge levels of tenants and property managers regarding environmentally sustainable retrofits and the benefits that could be realised: 'There is no consistent way that features are communicated, in a way that matters to and can be considered by tenants when choosing a house'. The need for a clear communications platform was further shown in this quote 'If there is any promotion of my retrofitted properties that can have it outstanding and [more] easily ... let out than nonretrofitted properties. Any website or information can be given to potential tenants to let them 
know the advantages of renting a retrofitted properties [sic]'. Clear, informative communication targeting all stakeholders was seen as critical in developing a framework to support greater uptake of environmental retrofitting. However, these research findings suggest that communication strategies have had limited effect to date.

Another key theme identified from the data relates to regulation. A lack of regulation was identified as a barrier, and increased regulations was seen as an enabling force. The limited regulation across the different levels of government was seen to reinforce the culture of the investment priority of rental properties: 'Changes to legislation [are needed] to make landlords complete the changes in the property'. One panel member highlighted from past experience that there needs to be a level of enforcement for changes to be effective:

'Our experience and analysis of other policy initiatives (we particularly point to and can discuss the experience of the Power Savers program, requirements around pool safety in NSW and installation of the NBN) suggests that what is necessary are enforceable requirements applied to property owners'.

Concepts and ideas around the facilitation of the process were highlighted by the experts as another key theme. The difficulty of implementing environmentally sustainable retrofits was identified as a barrier: Inconvenience - retrofitting may cause significant inconvenience for both landlord and tenants'. Policymakers need to consider the impact and 'hassle factor' of strategies moving forward, making them as easy as possible for key stakeholders to adopt, particularly landlords.

Finally, the rental market emerged as a contextual theme. Some panel experts believed that the balance between supply and demand of rental properties would influence the motivation to adopt environmentally sustainable retrofits: 'Constantly rising real estate (land) prices undercut the motivation to maintain or improve the building stock'. This is further illustrated in Tables 3 and 4. 


\section{Policy Delphi Round 2:}

In the second round of the Policy Delph study, 34 experts responded to both open- and closed-ended questions. Questions were developed based on the analysis of Round 1 data, leading to further consideration of six key enabling forces. Perceptions regarding key enabling forces were analysed using a combination of qualitative and quantitative methods. Quantitatively, both means and consensus analysis were undertaken using five-point Likert scales $(1=$ not at all important, $5=$ extremely important $)$. Consensus analysis identified the level of agreement within the expert panel regarding each enabling force. As shown in Table 5, return on investment and upfront cost reduction both had high consensus levels coupled with the strongest mean scores, 4.24 and 4.12 respectively. Ease of implementation and market conditions had a medium level of consensus across the expert panel, and their mean scores were 4.00 and 2.94 respectively. Finally, education and increased legislation both had low consensus within the sample and had mean scores of 3.52 and 3.70 respectively. These differences were explored further in Round 3 of this study. Quotes from the panel are presented alongside the quantitative data in Table 5 to capture the essence of these enabling forces. 
Table 5. Round 2 - Data presentation.

\begin{tabular}{|c|c|c|c|}
\hline Enablers for ESR & $\begin{array}{l}\text { Consensus } \\
\text { Analysis* }\end{array}$ & $\begin{array}{l}\text { Mean } \\
(\text { Stddev)** } \\
\mathbf{n}=\mathbf{3 4}\end{array}$ & Indicative Expert Panel Quotes \\
\hline $\begin{array}{l}\text { Return on } \\
\text { Investment } \\
\text { (Incentivisation) }\end{array}$ & High & $4.24(.969)$ & $\begin{array}{l}\text { - It is all about the ROI, more in landlords pocket more } \\
\text { inclined to proceed. } \\
\text { - Most investment properties are held for cash flow or } \\
\text { wealth creation purposes so ROI is extremely } \\
\text { important }\end{array}$ \\
\hline $\begin{array}{l}\text { Upfront cost } \\
\text { reduction } \\
\text { (incentivistation) }\end{array}$ & High & $4.12(.992)$ & $\begin{array}{l}\text { - When the vacancy rate is low, landlords have the } \\
\text { power and will need incentives to upgrade the home } \\
\text { rather than re-lease to the next tenant. } \\
\text { - Upfront cost is one of the main factor for landlords } \\
\text { not undertaking such retrofitting; and a cost reduction } \\
\text { will definitely help }\end{array}$ \\
\hline $\begin{array}{l}\text { Ease of } \\
\text { implementation } \\
\text { (Facilitation) }\end{array}$ & Medium & $4.00(.829)$ & $\begin{array}{l}\text { - The hassle of organising upgrades is a disincentive, } \\
\text { as is the inconvenience to the current tenant (who may } \\
\text { request a rental discount while works are carried out). } \\
\text { - Making things easy for people is definitely the key to } \\
\text { getting things happening. } \\
\text { - I believe landlords, on the whole, will only } \\
\text { implements changes if it is easy-if it is too hard they } \\
\text { just won't do it. }\end{array}$ \\
\hline $\begin{array}{l}\text { Increased } \\
\text { legislation } \\
\text { (Regulation) }\end{array}$ & Low & $3.70(1.31)$ & $\begin{array}{l}\text { - Setting legislative requirements is a strong way to } \\
\text { guarantee (enact) change. } \\
\text { - Regulations and standards that universally raise } \\
\text { sustainability levels and standards are crucial to } \\
\text { ensure a level playing field, a fair market, and } \\
\text { minimum perverse outcomes or market distortions. } \\
\text { - If any real change is to occur, there needs to be some } \\
\text { sort of legislative push rather than only using financial } \\
\text { gains (short or long term) to entice uptake. }\end{array}$ \\
\hline $\begin{array}{l}\text { Education } \\
\text { (Communication) }\end{array}$ & Low & $3.52(1.21)$ & $\begin{array}{l}\text { - Education is key, getting people to understand the } \\
\text { benefits and potential pitfalls is vital to the success of } \\
\text { any program or idea. } \\
\text { - "If you think education is expensive, try ignorance." } \\
\text { - If more know/think it is actually easier than they } \\
\text { imagined, this could be an important pull factor. }\end{array}$ \\
\hline $\begin{array}{l}\text { Rental market } \\
\text { conditions }\end{array}$ & Medium & $2.94(1.12)$ & $\begin{array}{l}\text { - The threat of long-term vacancy would motivate } \\
\text { landlords to invest in their property to give it a market } \\
\text { edge. } \\
\text { - A significant increase (to at least an overall rate of } \\
5 \% \text { ) in available rentals at all price points will } \\
\text { theoretically bring pressure on a number landlords to } \\
\text { retrofit and hope to recoup the benefit of their } \\
\text { investment by making the property more attractive. }\end{array}$ \\
\hline * Consensus analysis: & $\begin{array}{l}\text { High }>=65 \% \\
\text { Medium }>=5 \\
\text { Low }>=45 \% \\
\text { None }<50 \%\end{array}$ & $\begin{array}{l}\text { ne or } 75 \% \text { in t } \\
\text { none or } 65 \% \\
\text { he or } 55 \% \text { in } t\end{array}$ & $\begin{array}{l}\text { vo contiguous categories on the Likert scale } \\
\mathrm{n} \text { two contiguous categories on the Likert scale } \\
\text { o contiguous categories on the Likert scale } \\
\text { ategories on the Likert scale }\end{array}$ \\
\hline
\end{tabular}




\section{Policy Delphi Round 3:}

A total of 26 experts participated in the third round of the Policy Delphi study. Respondents were asked their underlying philosophical view on the environmentally sustainable retrofitting of rental properties in an attempt to gain further insight into the similarities and differences within the expert panel. Experts selected one of the two statements below and were categorised according to their beliefs:

- The rental house is a significant investment for the landlord and any changes to increase the environmental sustainability of the property should not impact negatively on this investment (Investment orientation $n=16$ )

- The need to increase the environmental sustainability of the rental housing stock in Australia overrides the ROI (return on investment) concerns of landlords (Sustainability orientation $n=10)$

Experts allocated 100 points across the six enabling forces. Table 6 shows the mean scores both overall, and for the investment and sustainability oriented experts. Overall, an increase in legislation was ranked highest (26.27), closely followed by upfront cost reductions (25.54). Variation in the importance the sustainability oriented experts placed on increased legislation was noticeable, suggesting that in their view, there is a clear need for government intervention to progress this agenda. As would be expected, there were differences in means for the incentivisation factors of upfront investment (28.69 and 20.50) and return on investment (24.69 and 13.00) between the investment and sustainability orientated experts. However, these are not as pronounced as might be anticipated, as both groups still ranked these factors in their top three. The key takeaway from this analysis is the complex and multifaceted nature of possible solutions. Thus, a conceptual framework will need to embrace all of these forces, at varying degrees, to achieve workable outcomes. 
Table 6. Indication of the importance of enabling forces for moving towards a Sustainable Private Rental Sector.

\begin{tabular}{llll}
\hline Enablers for ESR & $\begin{array}{l}\text { Expert Panel } \\
\boldsymbol{n = 2 6}\end{array}$ & $\begin{array}{l}\text { Means (order) } \\
\text { Investment } \\
\text { Experts } \\
\boldsymbol{n = 1 6}\end{array}$ & $\begin{array}{l}\text { Means (order) } \\
\text { Sustainability } \\
\text { Experts } \\
\boldsymbol{n = 1 0}\end{array}$ \\
\hline Increased legislation (R) & $26.27(1)$ & $19.56(3)$ & $37.00(1)$ \\
Upfront cost reduction (I) & $25.54(2)$ & $28.69(1)$ & $20.50(2)$ \\
Return on investment (I) & $20.19(3)$ & $24.69(2)$ & $13.00(3)$ \\
Ease of implementation (F) & $14.35(4)$ & $15.19(4)$ & $13.00(3)$ \\
Education/Communication (C) & $7.81(5)$ & $7.38(5)$ & $8.50(5)$ \\
Rental market conditions (M) & $5.85(6)$ & $4.50 \quad(6)$ & $8.00(6)$ \\
\hline 100 point allo
\end{tabular}

100 points allocated between the 6 enabling forces by the expert panel

Key: (R) Regulation theme; (I) Incentivisation theme; (F) Facilitation theme; (C) Communication theme; (M) Rental market contextual theme

Table 7 shows the mean scores (overall, and for the investment and sustainability oriented experts) for respondents' allocation of 100 points to the importance of the key stakeholder groups in the shift to a more sustainable rental sector. The six stakeholders were seen, to varying degrees, as important in the process. However, Landlords (37.38) and Government (29.12) were the main players as identified by the expert panel. Unsurprisingly, the sustainability orientated experts placed a lower level of emphasis on the landlords when compared with the investment experts (27.50 and 43.56), and placed more emphasis on property managers (17.00) and tenants (12.50) as part of the solution. 
Table 7. Importance of key stakeholders for moving towards a Sustainable Private Rental Sector

\begin{tabular}{llll}
\hline Stakeholders & $\begin{array}{l}\text { Expert Panel } \\
\boldsymbol{n = 2 6}\end{array}$ & $\begin{array}{l}\text { Means (order) } \\
\text { Investment } \\
\text { experts } \\
\boldsymbol{n = 1 6}\end{array}$ & $\begin{array}{l}\text { Means (order) } \\
\text { Sustainability } \\
\text { Experts } \\
\boldsymbol{n}=\mathbf{1 0}\end{array}$ \\
\hline Landlords & $37.38(1)$ & $43.56(1)$ & $27.50(2)$ \\
Government & $29.12(2)$ & $27.94(2)$ & $31.00(1)$ \\
Property Managers & $11.54(3)$ & $8.13 \quad(5)$ & $17.00(3)$ \\
Tenants & $10.04(4)$ & $8.50(3)$ & $12.50(4)$ \\
Industry & $6.92(5)$ & $8.44(4)$ & $4.50(6)$ \\
Financial Institutions & $5.00(6)$ & $3.44 \quad(6)$ & $7.50 \quad(5)$ \\
\hline
\end{tabular}

- 100 points allocated between the 6 key stakeholder by the expert panel

The four quotes below highlight the differing views within the expert panel around the role the two key stakeholders (landlords and governments) should play in moving towards an environmentally sustainable rental sector:

'Given our situation regarding carbon emissions and climate change, I think we actually need to start taking action. Clear decisive action. The landlords will adapt - a period of change would be wise to assist them to either get out of the market or plan and budget for change'.

'Landlords are investing in rental property primarily for financial gain. They need to be convinced or regulated for the changes to occur'.

'Government are the key instrument in terms of providing the stringent policy and legislative requirements... Government regulation this will enforce landlords to change and make tenants more aware - particularly if there is mandatory disclosure'. 
'Landlords need to implement so they are primary. Governments need to make the rules/provide the funding, Tenants help to drive demand - although this is not essential if policies are driven by government'

These quotes speak to the complexity of the system, where multiple stakeholders will need to be considered in an evolving framework.

\section{Round 4 - In-depth Interviews:}

In Round 4 of this research project involved undertaking six in-depth interviews were undertaken with a cross section of the expert panel. The aim of this round was twofold: firstly, to clarify and validate the enabling forces that emerged through the three previous rounds; and secondly, to further explore and test the evolving conceptual framework for the task of moving towards a sustainable private rental sector. Whilst limited new data emerged from this round, the five key themes of communication (lack of awareness/education), facilitation (ease of implementation), incentivisation (return on investment/upfront cost reduction), regulation (increased legislation), and rental market conditions were validated as important enabling forces that need to be considered in the successful transition to an environmentally sustainable rental sector.

Two interesting quotes from this round speak to a need for a cultural shift in how the rental market is viewed overall:

If you are a country, state, or city that already has expectations of the quality then it is probably going to be easier to enter energy carbon standards for rental properties. Here we don't have this! You are not only introducing carbon standards, you are actually needing to encourage and introduce a culture of compliance overall. 
Maybe the most fundamental change is changing the relationship between owners

and occupants. Housing is an essential service [but not seen as one]; and if you are investing in an essential service you are bound by a lot of rules.

This idea, of the need for government intervention, to move this agenda forward emerged in all rounds of this research project.

In summary, the four rounds of research undertaken in this Policy Delphi study provided data from a range of experts that, when analysed, led to the identification of enabling forces, coupled with the processes needed to move toward a sustainable private rental sector. The following discussion section identifies a conceptual framework which integrates the enabling forces with the rental market and stakeholders to frame an environmentally sustainable PRS as a win-win-win scenario for property owners, tenants and the environment.

\section{Discussion}

Climate change is a reality that will have major impacts on humanity during this century. The evidence of sea level rise, increases in temperatures and extreme heat events, have all been documented and are beyond dispute. Whilst the specific impact this will have on the housing stock in Australia is unclear, logic dictates that increased temperatures and severe weather events will have an adverse impact on the comfort level of residents living in poorer quality houses, many of which are rental properties. This will likely have major impacts for occupants of rental properties (e.g. through increases in energy used to sustain comfort levels, resulting in increased $\mathrm{CO}_{2}$ emissions and additional costs to the tenants, or, negative impacts on health in cases where tenants cannot increase their comfort levels for financial or other reasons).

Consequently, there is an urgent need for policy and market-based initiatives to increase the environmental sustainability of rental properties. However, for these solutions to be successful there needs to be a clear understanding of the interplay between enabling forces and 
stakeholders. Remarkably, existing research sheds little light on this issue (Instone et al., 2015). The purpose of this study is therefore to extend current knowledge by not only identifying the barriers and enablers, but also their interplay within the context of the PRS. In doing so, this study builds on previous research to introduce a conceptual framework that offers a more nuanced understanding of the task of moving to a more environmentally sustainable rental sector.

Within this study, there was an emphasis on the rental house being seen by landlords as an investment, with the needs of the tenants being secondary to the performance of the investment. Correspondingly, and in support of previous studies (e.g., Stone et al., 2015; Wrigley \& Crawford, 2017), financial barriers were perceived by the panel of experts to present the strongest impediment to retrofitting. These financial barriers are identified both in terms of the cost of investing in environmentally sustainable retrofits (Hope \& Booth, 2014), and in the lack of potential for return on investment due to perceptions of split incentives (NSW Government, 2016). However, in the ACT, where there is a requirement to disclose the energy efficiency rating of a property at the point of sale or lease, the rental price of properties is positively affected by both a higher energy efficiency rating, and the presence of energy saving features (Fuerst \& Warren-Myers, 2018). This is also the case internationally, where a study in the U.S. showed that a premium of $6-14 \%$ could be achieved for houses with energy efficient features (Im et al., 2017). This suggests that split incentives are perhaps more of a perception than a reality. When people are provided with energy performance information, there is an impact on their decision-making, and a return on investment is achieved for the landlord.

Support to overcome the financial barriers to retrofitting was the second most affirmed enabler by the panel of experts in both Round 2 and Round 3 of the Policy Delphi. The provision of financial incentives in the form of either grants/subsidies or tax incentives was suggested by the panel of experts. However, Phillips (2012) found that in New Zealand, the 
uptake of grants for the insulation of properties was significantly lower within the private rental sector than amongst owner-occupiers. This could be a result of the difficulty of implementation of retrofits as highlighted earlier in this study - often referred to by panellists as the 'hassle factor'. Similarly, Hope and Booth (2014) found that financial mechanisms introduced to address energy efficiency in the UK, such as the Green Deal, were too complex and hence uptake was limited. This clearly illustrates the inefficiency of addressing barriers individually and the need for enablers to work cohesively.

A lack of awareness and knowledge of the potential benefits of environmentally sustainable retrofitting across all actors in the private rental sector was identified as a barrier. However, as illustrated in the Low Income Energy Efficiency Program in Victoria, Australia, these information problems can be overcome with correctly designed interventions (Button et al., 2016). One stakeholder group that was identified as a possible conduit in the information dissemination process was property managers, who have the potential to influence landlord decision-making. Significantly, the proportion of Australian rental properties under the management of a real estate agent increased from 68 to 75 percent from 2006 to 2016 (Hulse et al., 2018) and is as high as 81 percent in Sydney. The potential for property managers in this information dissemination role warrants further investigation.

A lack of regulations relating to the energy efficiency of rental homes was identified as a significant barrier throughout the Policy Delphi rounds. Indeed, the provision of increased legislation, both in the form of disclosure of building energy performance, and the introduction of minimum standards, was the most highly ranked enabler in Round 3 of the Policy Delphi. Although this combination of legislation for rental homes was one in a series of options proposed by NSW Government (2016), as yet, these policies have not been progressed.

One market condition identified as a barrier by the expert panel was the short-term nature of leases, which often prevents renters investing in retrofits for their own benefit 
(Wrigley \& Crawford, 2015; Ambrose, 2015). In the social housing sector, the characteristics of long leases and common ownership of a portfolio of properties present fewer barriers to the environmentally sustainable retrofitting of properties (Vaughan, 2019). The experts also identified an undersupply of rental housing as a barrier to improved quality of rental housing, stating that there is no need for landlords to upgrade their properties. Whilst legislation could be changed to address the issue of short term leases, the supply of rental properties presents a more complex problem to address.

The responses summarised in Tables 4 and 5 highlight a diverse range of enablers resulting from the initial questions posed to panellists. These enablers were grouped into six themes: return on investment, upfront cost reduction, ease of implementation, increased legislation, education, and rental market conditions. Analysis of the results of the Policy Delphi study makes apparent the complexity of the socio-technical system that is the private rental sector (Horne et al. 2016), and responses illustrate that no single enabling force can act as a panacea - instead the forces need to act together to bring about positive change. In considering the task of moving towards a more environmentally sustainable rental sector, we have conceptualised this process as comprising three elements: the goal, the rental market, and a set of enabling forces which can act on the rental market to move it towards or away from the goal. Figure 1 presents our conceptual framework, which identifies the interaction between the various activities and actors involved in achieving the goal. 


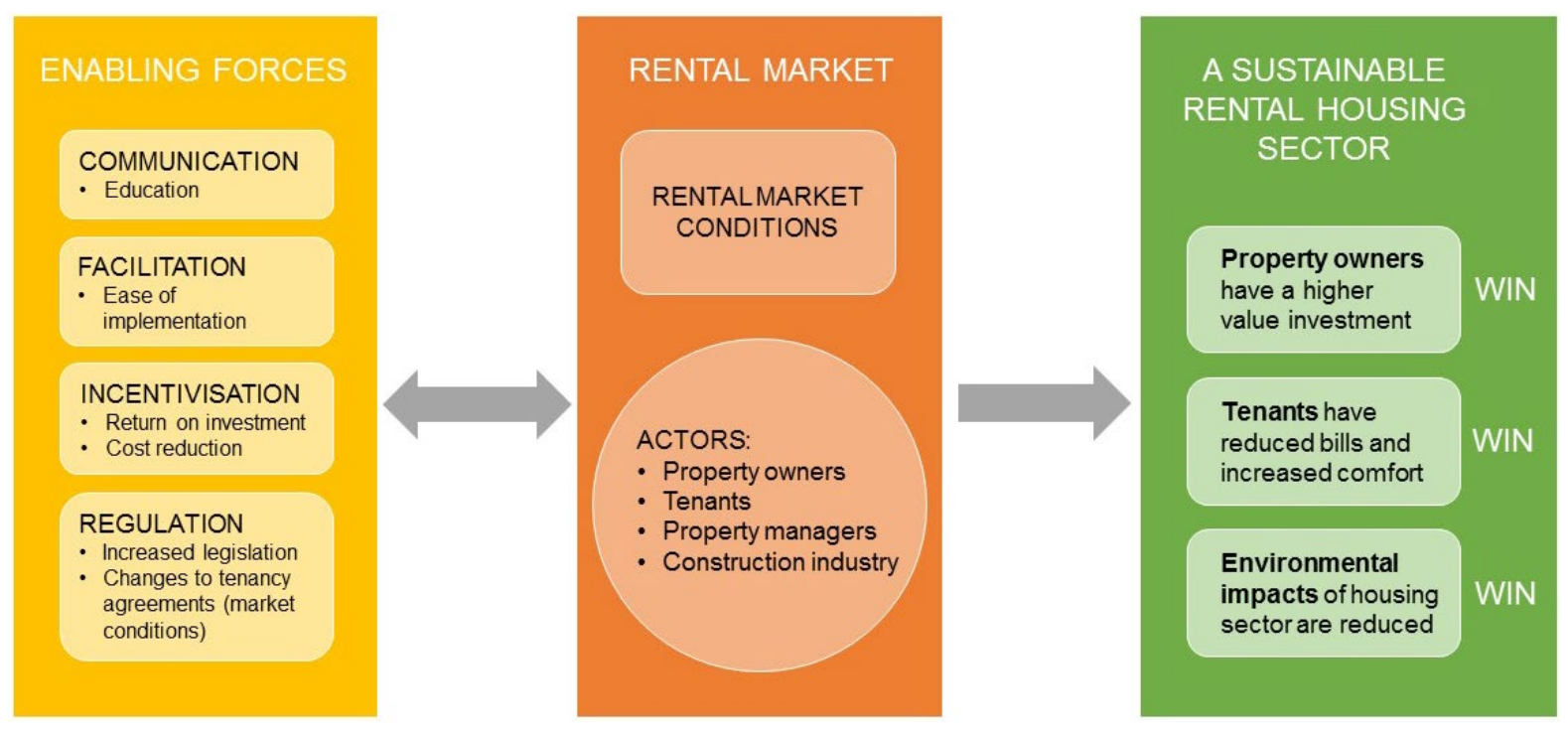

Figure 1. Conceptual framework for the task of moving towards a Sustainable Private Rental Sector.

Four enabling forces are identified, which consolidate the six themes adopted in the Policy Delphi study. The enabling forces are: (1) communication, (2) facilitation, (3) incentivisation, and (4) regulation. The conceptual model proposes that any regulatory or market-based initiatives aimed at enhancing the environmental sustainability of rental premises need to activate multiple enabling forces in order to have the greatest chance of success and uptake by landlords. It is believed that the successful transition to a sustainable rental housing sector will generate benefits for landlords, tenants, and the environment. For example, if an initiative was put forward to increase the insulation of rental properties, and was communicated, facilitated and incentivised correctly, landlords would view this as a WIN as it enhances their asset and makes it more attractive to rent. The tenants would also view this as a WIN as they would live in a more comfortable house with reduced energy bills. Finally, the environment WINs as less $\mathrm{CO}_{2}$ is being emitted into the atmosphere.

A further dynamic of the conceptual model is the influence of the rental market on the system. The rental market comprises both the actors and the market conditions. The actors include: property owners, tenants, property managers, the construction industry, and public 
sector policymakers. Current market conditions emerged as a barrier to the successful uptake of environmentally sustainable initiatives for rental properties, as, at the time of writing, demand for rental housing exceeds supply in many parts of Australia. However, the rental market fluctuates over time, and these fluctuations will put different pressures on the regulatory environment, property owners and tenants. For the individual property owner or tenant the power dynamic will change depending on supply in the market. Oversupply will mean that property owners will need to do more to attract tenants, which could include environmentally sustainable retrofitting which will likely not occur in periods of undersupply. However, policy initiatives are not only influenced by market forces, but can strongly influence the market, as illustrated in the conceptual framework.

\section{Conclusions}

This Policy Delphi study with experts on the PRS has identified and elucidated barriers and enablers to environmentally sustainable retrofitting of rental houses. In this paper a conceptual framework has been developed which illustrates the interaction between the enabling forces, actors and rental market. The conceptual framework presented should be utilised at the outset of strategy discussions. As policy or market-based solutions need to consider not only rental market dynamics and key stakeholders, but also how to communicate, facilitate, incentivise and regulate in order to achieve the goal of making the rental sector more sustainable.

A logical next stage of research into a sustainable private rental sector could explore how this conceptual framework would be operationalised for policy-based solutions such as minimum rental housing standards or tax incentives. How could these solutions be communicated, facilitated, incentivised and regulated for greatest effect? Methodologically, this could take the form of choice-modelling experiments highlighting different policy/marketbased options at different levels of communication, facilitation, incentivisation and regulation, 
to the key stakeholder groups, with the aim of identifying the best balance of the enabling forces for each scenario.

Whilst the research described herein is limited by the particular methods used (Policy Delphi study and in-depth interviews), coupled with the sample group of experts utilised over a finite period of time, the findings enhanced our understanding of the interplay between enablers, processes and people that can help move towards a sustainable private rental sector. The findings to emerge from this study, whilst developed within the Australian context, can be used to signpost researchers, advocates and policymakers, from around the world, on the important preconditions to consider when moving this critical agenda forward.

In conclusion, it is hoped that this research enhances the body of work in this area, providing key decision-makers with an evidence-based foundation on which to construct strategy. It is only through informed, appropriate and coordinated action that the challenges presented by climate change will be tackled. Whilst environmental sustainability of rental properties is one small piece in a very large climate change puzzle, it remains an important piece. 


\section{References}

Ambrose, A. R. (2015) Improving energy efficiency in private rented housing: Why don't landlords act? Indoor and Built Environment, 24(7), pp. 913-924.

Australian Building Codes Board (ABCB) (2016) Upgrading Existing Buildings Handbook, Commonwealth of Australia and States and Territories of Australia.

Australian Bureau of Statistics (2016) Census QuickStats. Retrieved from http://quickstats.censusdata.abs.gov.au/census_services/getproduct/census/2016/quickst at/036.

Australian Council of Social Service (ACOSS) (2013) Energy Efficiency \& People on Low Incomes. Strawberry Hills, NSW, Australia: Australian Council of Social Service.

Australian Council of Social Service, Brotherhood of St Laurence, \& The Climate Institute. (2017) Empowering disadvantaged households to access affordable, clean energy. Australian Government Department of the Environment and Energy (2017) Review of Climate Change Policies. Commonwealth of Australia.

Australian Government Department of the Environment and Energy (2018) National Inventory by Economic Sector 2016. Australia's National Greenhouse Accounts. Canberra: Commonwealth of Australia.

Australian Government, Department of the Environment and Energy (2019) Quarterly Update of Australia's National Greenhouse Gas Inventory: March 2019, Commonwealth of Australia.

Bailey, R., Longhurst, J. W. S., Hayes, E. T., Hudson, L., Ragnarsdottir, K. V., \& Thumim, J. (2012) Exploring a city's potential low carbon futures using Delphi methods: Some preliminary findings. Journal of Environmental Planning and Management, 55(8), pp. 1022-1046.

Better Renting (2018) Four in ten Canberra rentals score worst energy efficiency rating. Retrieved from https://www.betterrenting.org.au/energy_efficiency_report. 
Bird, S., \& Hernández, D. (2012) Policy options for the split incentive: Increasing energy efficiency for low-income renters, Energy Policy, 48, pp. 506-514.

Bosch, J., Palència, L., Malmusi, D., Marí-Dell'Olmo, M. and Borrell, C. (2019) The impact of fuel poverty upon self-reported health status among the low-income population in Europe, Housing Studies, 34(9), pp.1-27.

Bouzarovski, S., \& Petrova, S. (2015) A global perspective on domestic energy deprivation: Overcoming the energy poverty-fuel poverty binary, Energy Research \& Social Science, 10, pp. 31-40.

Byrne, M., (2019) The financialization of housing and the growth of the private rental sector in Ireland, the UK and Spain. UCD Geary institute for Public Policy Discussion Paper Series (No. 201902).

Button, L., Lodge, G., \& Taylor D. (2016) Low Income Energy Efficiency Program. CV Community Energy. Murchison, Victoria.

Cajias, M., Fuerst, F., \& Bienert, S. (2019) Tearing down the information barrier: the price impacts of energy efficiency ratings for buildings in the German rental market, Energy Research \& Social Science, 47, pp. 177-191.

Charlier, D. (2015) Energy efficiency investments in the context of split incentives among French households, Energy Policy, 87, pp. 465-479.

Chegut, A., Eichholtz, P., \& Holtermans, R. (2016) Energy efficiency and economic value in affordable housing, Energy Policy, 97, pp. 39-49.

Chisholm, E., Howden-Chapman, P., \& Fougere, G. (2017) Renting in New Zealand: perspectives from tenant advocates, Kotuitui-New Zealand Journal of Social Sciences Online, 12(1), pp. 95-110. 
Consumer Action Law Centre (2015) Heat or Eat. Households should not be forced to decide whether they heat or eat. Available at https://consumeraction.org.au/wpcontent/uploads/2015/08/Heat-or-Eat-Consumer-Action-Law-Centre.pdf.

Cooper, P., Gordon, R., Waitt, G., Petkovic, D., Burroughs, N., Tibbs, M., Butler, K., Roggeveen, K., McDowell, C., Kokogiannakis, G., Ledo Gomis, L., \& Magee, C. (2016) EE3A: Pathways and initiatives for low-income older people to manage energy. Final Report. Available at https://www.energy.gov.au/sites/default/files/regional_development_australia_illawarra energy_efficiency in the 3 rd_age.pdf.

Council of Australian Governments Energy Council (2016) National collaborative approach to residential building ratings and disclosure-principles. Canberra: COAG Energy Council.

Crook, T., \& Kemp, P. A. (2014) Comparing countries. In T. Crook \& P. A. Kemp (Eds), Private Rental Housing: Comparative Perspectives, pp. 224-246 (Cheltenham, U.K.: Edward Elgar).

Crawford, R. \& Stephan, A. (2015), Living and Learning: Research for a Better Built Environment: 49th International Conference of the Architectural Science Association, pp.322-331, The Architectural Science Association and The University of Melbourne, found at http://anzasca.net/wpcontent/uploads/2015/12/031_Wrigley_Crawford_ASA2015.pdf, pp. 324.

Davenport, C. (2015) Nations Approve Landmark Climate Accord in Paris. The New York Times, 12 December. Available at https://www.nytimes.com/2015/12/13/world/europe/climate-change-accord-paris.html. de Loe, R. C. (1995) Exploring complex policy questions using the policy Delphi. A multiround, interactive survey method. Applied Geography, 15(1), pp. 53-68. 
de T'Serclaes, P., \& Jollands, N. (2007) Mind the gap: quantifying principal-agent problems in energy efficiency. Available at https://www.iea.org/publications/freepublications/publication/mind the gap.pdf. Department of the Environment and Energy (2019) Nationwide House Energy Rating Scheme (NatHERS). Retrieved from http://www.nathers.gov.au.

Duffy, D., Kelleher, C., \& Hughes, A. (2017) Landlord attitudes to the private rented sector in Ireland: survey results. Housing Studies, 32(6), pp. 778-792.

Etikan, I., Musa, S. A. \& Alkassim, R. S. (2016) Comparison of convenience sampling and purposive sampling, American Journal of Theoretical and Applied Statistics, 5, pp. 1-4. Fuerst, F., McAllister, P., Nanda, A. and Wyatt, P., (2015) Does energy efficiency matter to home-buyers? An investigation of EPC ratings and transaction prices in England. Energy Economics, 48, pp.145-156.

Fuerst, F. \& Warren-Myers, G. (2018) Does voluntary disclosure create a green lemon problem? Energy-efficiency ratings and house prices. Energy Economics, 74, pp. 1-12.

Gabriel, M., Watson, P., Ong, R., Wood, G., \& Wulff, M. (2010) The environmental sustainability of Australia's private rental housing stock. AHURI Final Report No. 159 (pp. 113). Melbourne, Australia: Australian Housing and Urban Research Institute.

Ghaffarianhoseini, A., Dahlan, N. D., Berardi, U., Ghaffarianhoseini, A., Makaremi, N., \& Ghaffarianhoseini, M. (2013) Sustainable energy performances of green buildings: A review of current theories, implementations and challenges, Renewable and Sustainable Energy Reviews, 25, pp. 1-17.

Hatvani-Kovacs, G., Belusko, M., Pockett, J., \& Boland, J. (2015) Drivers and barriers to heatwave-resilient building retrofitting in the Australian context, in R. H. Crawford \& A. Stephan (Eds) Living and Learning: Research for a Better Built Environment: 49th International Conference of the Architectural Science Association, pp. 13-22 
Hope, A. J., \& Booth, A. (2014) Attitudes and behaviours of private sector landlords towards the energy efficiency of tenanted homes, Energy Policy, 75, pp. 369-378.

Horne, R., Dalton, T., \& Moloney, S. (2015) Beyond the split incentive: Governing sociotechnical relations in private rental housing retrofit, In Retrofitting Cities, pp. 135-149. Routledge.

Howden-Chapman, P., Pierse, N., Nicholls, S., Gillespie-Bennett, J., Viggers, H., Cunningham, M., Phipps, R., Boulic, M., Fjallstrom, P., Free, S., \& Chapman, R. (2008) Effects of improved home heating on asthma in community dwelling children: randomised controlled trial, British Medical Journal, 337(7674), pp. 1-9.

Hulse, K., \& Yates, J. (2017) A private rental sector paradox: unpacking the effects of urban restructuring on housing market dynamics, Housing Studies, 32(3), 253-270.

Hulse, K., Burke, T., Ralston, L., \& Stone, W. (2012) The Australian private rental sector: changes and challenges. In AHURi Positioning Paper No. 149 (pp. 54). Melbourne: Australian Housing and Urban Research Institute. Swinburne Research Centre.

Hulse, K., Martin, C., James, A., \& Stone, W. (2018) Private rental in transition: institutional change, technology and innovation in Australia, AHURI Final Report No. 296. Available at http://www.ahuri.edu.au/research/final-reports/296.

Im, J., Seo, Y., Cetin, K. S., \& Singh, J. (2017) Energy efficiency in US residential rental housing: Adoption rates and impact on rent, Applied Energy, 205, pp. 1021-1033.

Instone, L., Mee, K. J., Palmer, J., Williams, M., \& Vaughan, N. (2015) Climate change adaptation in the rental sector. In J. P. Palutikof, S. L. Boulter, J. Barnett, \& D. Rissik (Eds), Applied studies in climate adaptation, pp. 372-379 (Chichester, West Sussex: John Wiley \& Sons).

Kholodilin, K. A., Mense, A., \& Michelsen, C. (2017) The market value of energy efficiency in buildings and the mode of tenure, Urban Studies, 54(14), pp. 3218-3238. 
Lewandowsky S. (2011) History shows Australia is no pissant when it comes to emissions. The Conversation (1 June). Retrieved from https://theconversation.com/history-showsaustralia-is-no-pissant-when-it-comes-to-emissions-1589.

Linstone, H. A., \& Turoff, M. (1975) The Delphi method: techniques and applications. Reading, M.A.: Addison-Wesley.

Liu, E., \& Judd, B. (2019) Regional variations in the experiences of energy poverty across Australia, Energy and Buildings, 196, pp. 293-298.

MacAskill, S., Stewart, R. A., Roca, E., Liu, B., \& Sahin, O. (2019) Green building, splitincentives and affordable rental housing policy, Housing Studies, 1-23. DOI: $10.1080 / 02673037.2019 .1677861$

Martinelli A. (2017) Bringing Rental Homes up to Scratch. Efficiency standards to cut energy bills, reduce pollution and create jobs. Environment Victoria. Available at https://environmentvictoria.org.au/wp-content/uploads/2017/09/Bringing-rental-homesup-to-scratch-Sept-2017-online.pdf.

Melvin, J. (2018) The split incentives energy efficiency problem: Evidence of underinvestment by landlords, Energy Policy, 115, pp. 342-352.

Needham, R. D., \& De Loe, R. C. (1990) The Policy Delphi - Purpose, Structure, and Application, Canadian Geographer-Geographe Canadien, 34(2), pp. 133-142.

New South Wales Parliament Legislative Council (2018) Select committee on electricity supply, demand and prices in New South Wales. Report 1 (22 November 2018).

NSW Council of Social Services (NCOSS) (2017) Turning Off The Lights. The Cost of Living in NSW. Retrieved from Woolloomooloo, NSW: https://www.ncoss.org.au/news-and-events/ncoss-news/turning-off-the-lights-the-costof-living-in-nsw. 
Organisation for Economic Co-operation and Development (2016) Housing Tenures. Paris: OECD Social Policy Division. http://www.oecd.org/els/family/HM1-3-Housingtenures.pdf.

Organisation for Economic Co-operation and Development (2018) Greenhouse gas emissions. https://stats.oecd.org/Index.aspx?DataSetCode=AIR_GHG.

Pachauri, R. K., \& Meyer, L. A. (2015) Climate Change 2014: Synthesis Report. Contribution of Working Groups I, II and III to the Fifth Assessment Report of the Intergovernmental Panel on Climate Change. Geneva, Switzerland https://www.ipcc.ch/site/assets/uploads/2018/02/SYR_AR5_FINAL_full.pdf

Padley, M. \& Marshall, L. (2019) Defining and measuring housing affordability using the Minimum Income Standard, Housing Studies 34(8), pp. 1307-1329.

Paraskevas, A., \& Saunders, M. N. K. (2012) Beyond consensus: an alternative use of Delphi enquiry in hospitality research, International Journal of Contemporary Hospitality Management, 24(6), pp. 907-924.

Pawson, H., Hulse, K., \& Morris, A. (2017) Interpreting the rise of long-term private renting in a liberal welfare regime context, Housing Studies, 32(8), pp. 1062-1084.

Phillips, Y. (2012) Landlords versus tenants: Information asymmetry and mismatched preferences for home energy efficiency, Energy Policy, 45, pp. 112-121.

Picavet, E., Cassiman, D. \& Simoens, S. (2012) Evaluating and improving orphan drug regulations in Europe: A Delphi policy study, Health Policy, 108, pp. 1-9.

Pitt \& Sherry. (2014) Reporting the energy efficiency of residential tenancies in the ACT. https://www.environment.act.gov.au/_ data/assets/pdf file/0005/701186/AttachmentA-Energy-Efficiency-Information-for-Tenants-Final-Consultation-Report.pdf.

Pivo, G. (2014) Unequal access to energy efficiency in US multifamily rental housing: opportunities to improve, Building Research and Information, 42(5), pp. 551-573. 
Powell, C. (2002) The Delphi technique: Myths and realities , Journal of Advanced Nursing, 41, pp. 376-382.

Prather M, Ehhalt D, Dentener F, Derwent R, \& Grubler A. (2001) Atmospheric chemistry and greenhouse gases. In Climate Change 2001: The Scientific Basis, Third Assessment Report, pp. 239-289, Geneva, Switzerland: IPCC: Working Group I of the Intergovernmental Panel on Climate Change.

Productivity Commission. (2012) Barriers to Effective Climate Change Adaption. In No. 59, Final Inquiry Report. Canberra: Commonwealth of Australia.

Rayens, M. K., \& Hahn, E. J. (2000) Building Consensus Using the Policy Delphi Method, Policy, Politics, \& Nursing Practice, 1(4), pp. 308-315.

Australian Capital Territory (2019) Residential Tenancies Act 1997. https://www.legislation.act.gov.au/a/1997-84/current/pdf/1997-84.pdf.

Rubin, H. J., \& Rubin, I. S. (2005) Qualitative interviewing: The art of hearing data, 2nd ed. (Thousand Oaks, CA: Sage).

Scanlon, K., \& Kochan, B. (Eds) (2011) Towards a sustainable private rented sector. London: The London School of Economics and Political Science.

State of NSW and Office of Environment and Heritage. (2016) A Draft Plan to Save NSW Energy and Money. A plan to meet the NSW Government's energy savings target and save money for NSW households and businesses. Available at https://www.environment.nsw.gov.au/-/media/OEH/CorporateSite/Documents/Climate-change/a-draft-plan-to-save-energy-money-160642.pdf.

Stone, W., Sharam, A., Wiesel, I., Ralston, L., Markkanen, S. \& James, A. (2015) Accessing and sustaining private rental tenancies: critical life events, housing shocks and insurances. AHURI Final Report No. 259, Australian Housing and Urban Research Institute Limited, Melbourne, https://www.ahuri.edu.au/research/final-reports/259. 
Tracy, S. J. (2013) Qualitative research methods, UK: Wiley-Blackwell.

Teddlie, C. and Tashakkori, A. (2003) Major issues and controversies in the use of mixed methods in the social and behavioural sciences. Handbook of mixed methods in social \& behavioural research, pp.3-50.

Teddlie, C., \& Yu, F. (2007) Mixed methods sampling: A typology with examples, Journal of mixed methods research, 1(1), pp. 77-100.

Turoff, M. (1970) The design of a policy Delphi, Technological Forecasting and Social Change, 2(2), pp. 149-171.

Vaughan, A. (2019) Dutch eco initiative halves energy bills in first UK homes. The Guardian-Australia edition, 8 January. https://www.theguardian.com/society/2019/jan/07/dutch-eco-homes-idea-arrives-in-ukand-cuts-energy-bills-in-half-nottingham-energiesprong.

Verstraete, J., \& Moris, M. (2018) Action-reaction. Survival strategies of tenants and landlords in the private rental sector in Belgium, Housing Studies. doi: $10.1080 / 02673037.2018 .1458290$

Waitt, G., Roggeveen, K., Gordon, R., Butler, K., \& Cooper, P. (2016) Tyrannies of thrift: Governmentality and older, low-income people's energy efficiency narratives in the Illawarra, Australia, Energy Policy, 90, pp. 37-45.

Whitehead, C., Scanlon, K., Monk, S., \& Tang, C. (2016) Understanding the Role of Private Renting. A Four-Country Case Study, Cambridge Centre for Housing and Planning Research and LSE London. Available at http://1selondonhousing.org/wpcontent/uploads/2016/10/Understanding-the-Role-of-Private-Renting_Web.pdf.

World Economic Forum. (2019) How to Set Up Effective Climate Governance on Corporate Boards, In collaboration with PwC, World Economic Forum, Switzerland. 
Wrigley, K., \& Crawford, R. H. (2015) Bridging the gap: energy efficiency improvements for rental properties. Paper presented at the Living and Learning: Research for a Better Built Environment, 49th International Conference of the Architectural Science Association, Melbourne, Australia.

Wrigley, K., \& Crawford, R. H. (2017) Identifying policy solutions for improving the energy efficiency of rental properties, Energy Policy, 108, pp. 369-378.

Wulff, M., \& Maher, C. (1998) Long-term Renters in the Australian Housing Market, Housing Studies, 13(1), pp. 83-98. 